\title{
Applications of Sustainable Materials in Concrete - A Short Review
}

\author{
P. Saravanakumar* \\ Civil Engineering Department, Sri Krishna College of Engineering and Technology, Coimbatore - 641008, \\ Tamil Nadu, India; psaravana2000@gmail.com
}

\begin{abstract}
Background/Objectives: Concrete is an inevitable material in construction industry. The major pollution from construction industry was reported from the production of materials like aggregates and cement. The material scarcity, supply-demand gap and environmental pollution insist the construction industry to find an alternative material for concrete matrix. The prime objective of this study is to review the past and recent research on the utilization of alternative materials in concrete production and its applications in construction industry. Materials and Methods: The abundant availability of recyclable waste materials like Construction and Demolition Wastes (C and DW) and industrial byproducts such as fly ash and slag increased the interest of the researchers towards application of these materials as an alternative source for cement and aggregate materials. Findings: Recycled Aggregate Concrete (RAC) showed less strength performance than normal concrete. To attain the similar strength performance of normal concrete, some modifications in the RAC mix design is required. The durability performance was highly improved with the application of industrial by product materials in concrete. Application/Improvement: This study possibly will help to encourage the consumers and further promote the use of alternative materials for concrete production on a larger scale in civil engineering projects.
\end{abstract}

Keywords: Concrete, Construction and Demolition Wastes, Fly Ash, Recycled Aggregate Concrete, Slag

\section{Introduction}

Recent research reports said that about $8 \%$ of the global annual $\mathrm{CO}_{2}$ emissions are due to concrete production. To meet-out the demands and to save the environment, construction industry started using alternative materials in concrete. Recycling C \& DW and use as an alternative for aggregates in concrete is a sustainable solution for waste disposal and depletion of natural resources. Using industrial by products as an alternative material for cement greatly reduce the environmental problem caused by these waste disposal.

In this paper applications of alternative materials like $\mathrm{C}$ \& DW, fly ash and Ground Granulated Blast Furnace Slag (GGBFS)in concrete were critically reviewed. Existing research reports about strength performances were reviewed and possible percentage application of alternative materials was highlighted based on the reports.

\section{Alternative Sustainable Materials}

\subsection{Construction and Demolition Waste (C \& DW) Aggregates}

Utilization of C \& DW aggregates as an alternative for virgin aggregate is not new and earlier it was majorly used as a base course in road construction. For concrete production the lack of confidence and awareness of using recycled materials and its production are the major reasons for not using RA in concrete. Nowadays using RA

*Author for correspondence 
in concrete was encouraged globally and many researchers positively reported about the performance of recycled aggregate concrete.

Many researchers carried out experiments by replacing Natural Aggregates (NA) with RA for different replacement percentages. Generally they reported that the strength and durability performance of RAC decreases with increase in RA percentage application in concrete. Many factors like, mortar adherence, texture, source of RA etc. were reported for the cause of this strength reduction. Among that the presence of mortar in the crushed recycled aggregate is the key factor for the performance reduction. For higher RA replacement, some modifications in mix design may be needed to ensure the equivalent performance of natural aggregate concrete.

Various different approaches like varying the mix proportion, methods of replacement (by volume or by weight), pre-soaking were experimented and reported by researchers. Among that, pre-soaking the aggregate before concreting showed better results $\stackrel{1}{\text {. }}$

The compressive strength reported by researchers ${ }^{2,9-12}$ for various percentage replacements of natural aggregate with recycled aggregates were shown in Figure 1. From the result comparison it was understood that the replacement of RA decreased the compressive strengths from $20 \%$ to $40 \%$ for $25 \%$ to $100 \%$ RA replacements.

Tensile strength of concrete is also one of the important characteristics of concrete. Many research reports stated that the higher percentage of RA application in concrete reduced the tensile strength characteristics. The tensile strength of RAC was decreased to an extent of $25 \%$ for $100 \%$ RA application in concrete ${ }^{2}$. Less than $10 \%$ difference in tensile strength at the age of 28 days between recycled aggregate concrete and control concrete also reported $\stackrel{3}{*}$.

To rectify this strength reduction in RA concrete various attempts like aggregate cleaning, using mineral admixtures in concrete, fibers addition in concrete were tried by researchers and reported its benefits. The RA in geopolymer concrete showed improved strength characteristics than ordinary RA concrete ${ }^{4}$.

\subsection{Fly Ash}

Earlier fly ash was used as landfill material and its disposal created a big environmental issue. Because of its abundant availability and pozzolanic property, globally it was tried and accepted as an alternative partial replacement material for cement. When it was used as a replacement material for cement it reacts with $\mathrm{CaOH}$ during the hydration and it produced Hydrated Calcium Silicate (CSH) and lime. By the time (90 days) fly ash reacts with the excess lime and produce more amount of hydrated calcium silicate which improves the strength gain of hardened concrete. The level of fly ash replacement was possibly tried and reported upto $60 \%$ of cement mass 5 . To overcome the environmental issues due to over utilization of cement in construction industry the application of fly ash as supplementary pozzolanic material is very important.

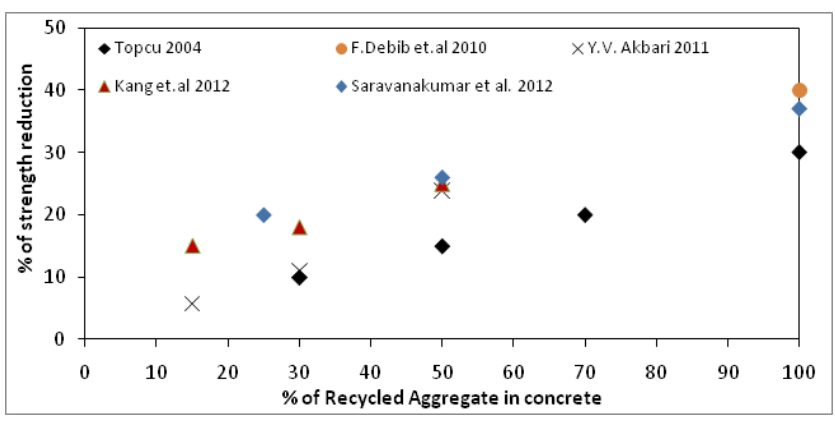

Figure 1. Result comparison of recycled aggregate concrete.

Nowadays high volume fly ash concrete was used in Dam construction and pavement base course projects. The Figures 2 and 3 showed the results reported by various researchers $\frac{5,13-16}{2}$ about the percentage strength reduction for various replacement percentage of cement with fly ash in concrete. From Figure 3 it was understood that significant strength gain of fly ash concrete was found in the later ages for all replacement percentages but not much changes were reported up to $20 \%$ replacement percentages.

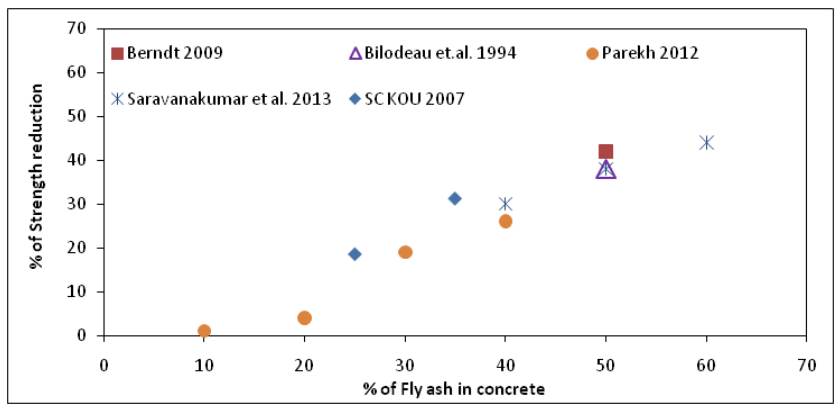

Figure 2. Result comparison of fly ash concrete after 28 days curing.

\subsection{Slag}

Utilization of slag as a partial replacement cementitious material for cement was globally recognized since from late 


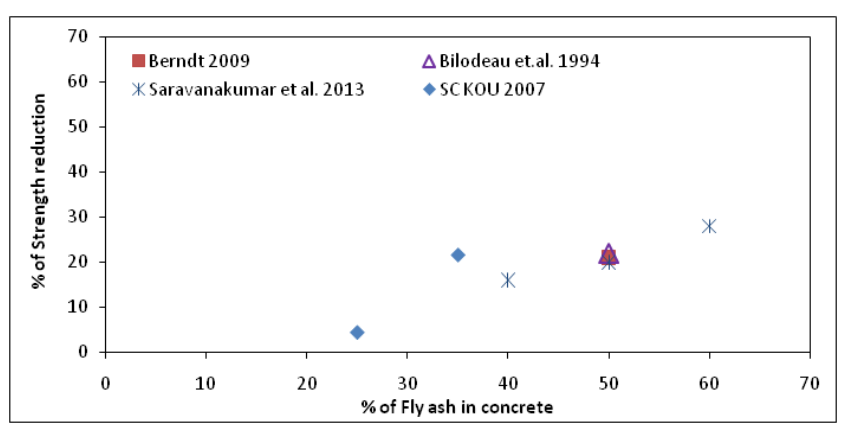

Figure 3. Result comparison of fly ash concrete after 90 days curing.

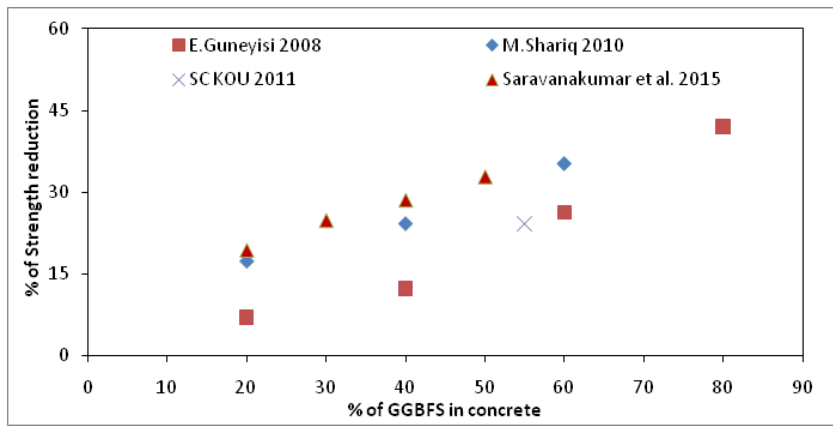

Figure 4. Result comparison of slag concrete after 28 days curing.

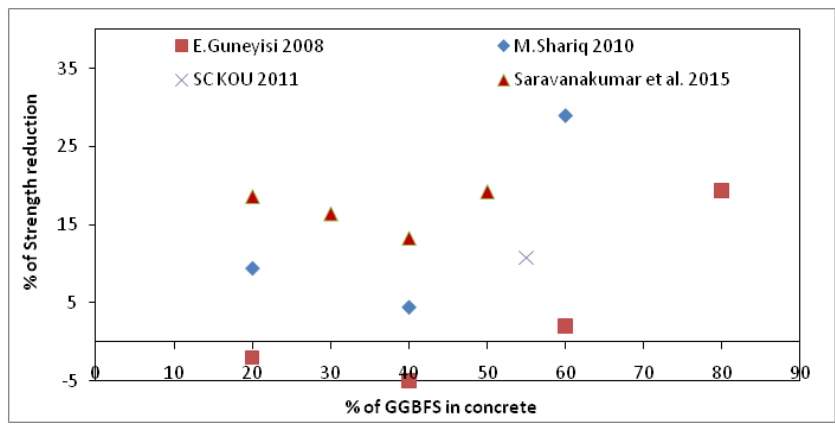

Figure 5. Result comparison of slag concrete after 90 days curing.

1950 [ACI Committee 233]. The main oxide components of blast furnace slag are Calcium oxide, Silica, Alumina and Magnesia. In general the high volume replacement of cement with slag in concrete resulted lesser performances than normal concrete at the early age but the rate of strength gain was higher than the normal concrete with time [ASTM C-989]. Many research reports were suggested to use slag as a replacement material for cement upto $30 \%$ without any ill effect. The higher presence of $\mathrm{CaO}(30-50 \%)$ in slag results strength improvement in concrete. It was reported that the rate of strength gain with $40 \%$ GGBFS concrete was found higher than the vir- gin aggregate concrete ${ }^{6}$. The level of replacement can also be tried and reported up to $55 \%$ positively in the field ${ }^{\mathrm{z}}$. The strength characteristics and its comparison at the earlier age andlater age for different percentage replacements of cement with GGBFS reported by researchers ${ }^{6,17-19}$ were shown in Figures 4 and 5. From the review it was understood that at the later ages the percentage strength gain of GGBFS concrete was found better than normal concrete. Many researchers reported that the fresh concrete characteristics of slag used concrete were remarkably improved because of its glassy texture. Similarly the durability performances like impermeability, alkali reaction, chloride resistance were also significantly enhanced in concrete with the increment of GGBFS quantity in concrete. For $20 \%$ to $50 \%$ GGBFS replacement level the impermeability performance of concrete was examined and found that the sorptivity value of concrete was decreased in the range of $5 \%$ to $25 \%$ than control concrete ${ }^{\frac{18}{}}$.

\section{Conclusions}

The above review of research reports mainly focused on application of alternative materials in concrete industry. The following conclusions were made from the above study report:

In RAC, gradually the strength was improved as in the case of NAC.

The mechanical characteristic of concrete was significantly reduced for higher replacement of RA.

The $40 \%$ strength reduction was observed in concrete having $100 \%$ recycled aggregates. Hence some modifications are required in concrete mix design to overcome this.

Significant improvement were found in strength gain at the later ages of concrete with more than $20 \%$ cement replacements with admixtures like fly ash and GGBFS. Upto $20 \%$ replacement levels not many changes were noticed.

Significant improvement in the durability characteristics like chloride ion penetration and sorptivity were found in concrete up to 50\% fly ash and GGBFS replacement level.

\section{References}

1. Wardeh G, Ghorbel E, Gomart H. Mix design and properties of recycled aggregate concretes: Applicability of Eurocode 2. International Journal of Concrete Structures 
and Materials. 2014; 9(1):1-20. https://doi.org/10.1007/ s40069-014-0087-y

2. Saravanakumar P, Dhinakaran G. Effect of admixed recycled aggregate concrete on properties of fresh and hardened concrete. Journal of Materials in Civil Engineering. 2012; 24(4):494-8. https://doi.org/10.1061/(ASCE)MT.19435533.0000393

3. Ajdukiewicz A, Kliszczewicz A. Influence of recycled aggregates on mechanical properties of HS/HPC. Cement Concrete Composites. 2002; 24(2):269-79. https://doi. org/10.1016/S0958-9465(01)00012-9

4. Saravanakumar P. Strength and durability studies on geopolymer recycled aggregate concrete. International Journal of Engineering and Technology. 2018; 7(2.24):370-5. https://doi.org/10.14419/ijet.v7i2.24.12087

5. Saravanakumar P, Dhinakaran G. Strength characteristics of high-volume flyash-based recycled aggregate concrete. Journal of Materials in Civil Engineering. 2013; 25(8):112733. https://doi.org/10.1061/(ASCE)MT.1943-5533.0000645

6. Saravanakumar P, Dhinakaran G. Mechanical and durability properties of slag based recycled aggregate concrete. Iranian Journal of Science and Technology. Transactions of Civil Engineering. 2015; 39-C2:271-82.

7. Oner A, Akyuz S. An experimental study on optimum usage of GGBS for the compressive strength of concrete. Cement and Concrete Composites. 2007; 29:505-14. https://doi. org/10.1016/j.cemconcomp.2007.01.001

8. Saravanakumar P, Abhiram K, Manoj B. Properties of treated recycled aggregates and its influence on concrete strength characteristics. Construction and Building Materials. 2016; 111:611-7. https://doi.org/10.1016/j.conbuildmat.2016.02.064

9. Topcu BI, Sengel S. Properties of concretes produced with waste concrete aggregate. Cement Concrete Research. 2004; 34(8):1307-12. https://doi.org/10.1016/j.cemconres.2003.12.019

10. Akbari YV, Arora NK, Vakil M. Effect on recycled aggregate on concrete properties. International Journal of Earth Sciences and Engineering. 2011; 4:924-8.
11. Debieb F, Courard L, Kenai S, Degeimbre R. Mechanical and durability properties of concrete using contaminated recycled aggregates. Cement and Concrete Composites. 2010; 32: 421-6. https://doi.org/10.1016/j.cemconcomp.2010.03.004

12. Kang THK, Kim W, Kwak YK, Hong SG. The choice of recycled concrete aggregates for flexural members. Proceedings of 18th International Association for Bridge and Structural Engineering Congress on Innovative Infrastructures; Seoul, Korea. 2012. https://doi.org/10.2749/222137912805111032

13. Berndt ML. Properties of sustainable concrete containing fly ash slag and recycled concrete aggregate. Construction and Building Materials. 2009; 23:2606-13. https://doi. org/10.1016/j.conbuildmat.2009.02.011

14. Bilodeau A, Sivasundaram V, Painter KE, Malhotra VM. Durability of concrete incorporating high volume fly ash from sources in the U.S. ACI Material Journal. 1994; 91(1):3-12. https://doi.org/10.14359/4411

15. Parekh DN, Modhera CD. Recycled aggregate fly ash concrete: An exploratory study. The IUP Journal of Structural Engineering. 2012; 5(3):7-19.

16. Kou SC, Poon CS, Chan D. Influence of fly ash as cement replacement on the properties of recycled aggregate concrete. Journal of Materials in Civil Engineering. 2007; 9(9):709-17. https://doi.org/10.1061/(ASCE)0899-1561(2007)19:9(709)

17. Guneyisi E, Gesoglu M. A study on durability properties of high-performance concretes incorporating high replacement levels of slag. Materials and Structures. 2008; 41(3):479-93. https://doi.org/10.1617/s11527-007-9260-y

18. Shariq M, Prasad J, Masood A. Effect of GGBFS on time dependent compressive strength of concrete. Construction and Building Materials. 2010; 24:1469-78. https://doi. org/10.1016/j.conbuildmat.2010.01.007

19. Kou SC, Poon CS, Francisco Agrela F. Comparisons of natural and recycled aggregate concretes prepared with the addition of different mineral admixtures. Cement and Concrete Composites. 2011; 33(8):788-95. https://doi. org/10.1016/j.cemconcomp.2011.05.009 